\title{
Patriarchy and Prejudice: Indian Women and Their Cinematic Representation
}

\author{
Abina Habib
}

\begin{abstract}
Nurtured by Indian culture and history women's role in commercial Indian films is that of a stereotypical woman, from the passive wife of Dadasaheb Phalke's Raja Harishchandra' (1913) to the long-suffering but heroic mother-figure of Mother India (1957) to the liberated Kangana Ranaut of Queen (2014), it has been a rather long and challenging journey for women in Hindi cinema. Although this role has been largely redefined by the Indian woman and reclaimed from the willfully suffering, angelic albeit voiceless female actor, the evolution is still incomplete. Culture and tradition mean different things for different women, but there is always the historical context of what it entails in the form of ownership. What this paper seeks to unravel is what being a woman means in Indian cinema. Indian film industry is one of the largest in the world, my effort then is to understand how an industry so vast caters to half of the world population. In today's globalized world, how are female actors treated? How do directors and female actors deal with vital issues of the three-pronged 'trishul', othering, violence, and voicelessness? What effects do films have on perceptions of beauty, sexuality, and gender? It is important to note that the sheer number of Hindi movies produced each year is huge and viewership is even greater, yet, in this globalized world, peppered with neocolonialism, caste distinctions, intolerance and aggression, the portrayal of Indian women in Hindi films creates, produces, and reinforces women's roles in a strictly heterosexual and rigid fashion. This does not allow for many variations in representation. Unarguably there has been some progression in Indian movies as in, they are more accessible but as far as improvement of the Indian woman is concerened, little progress has been made.
\end{abstract}

Index Terms-Cinema, identity, misogyny, patriarchy, stereotyping.

\section{INTRODUCTION}

Being a typical patriarchal society there exists a stern social structure in which the role of a woman is delineated, this specific role in the social scheme finds its way into the role of women in cinema as well. This is where the persuasion theory of alter-casting ${ }^{1}$ enters the discussion. According to Terry \& Hogg [1], this theory suggests, when a person accepts what is socially ordained they automatically feel the pressure to conform. The social environment expects the person to behave in a manner that is consistent with the role. Alter-casting means that we force an audience to accept a particular role that makes them behave in the way we want them to behave. Women have somehow inherited specific

Manuscript received June 4, 2017; revised September 5, 2017.

Abina Habib is with Amar Singh College, Srinagar, India (e-mail: abinahabib@gmail.com).

${ }^{1}$ Altercasting is a theory created by Eugene Weinstein and Paul Deutschberger in 1963. The theory relies on the concept of persuasion. Using many tactics, it is generally easy to pull off. social and cultural roles, which carry into the mainstream film industry and they end up being cast in similar roles. Inspired by 'Manusmriti' - an age old Dharmashastra written by Manu for followers of Hindu faith - a female actor is never allowed to transgresses the scriptural paradigm that mediates women's role as always in obedience and servitude to man, like Sita - the scriptural paradigm of femininity. The beginning of the woman's acting career seems to be governed by social norms and they mostly ended up playing the roles of a daughter, taking care of her siblings, helping the mother in the kitchen, and marrying the man of her father's choice, another typical role assigned to women is that of a great mother who is self-sacrificing, devoted and larger than life. This mother has no desires of her own nor does she have aspirations. The third and most abused image of a woman presented onscreen is the role of an ideal wife. Wife, such as Savitri, the immortalized image of an ideal woman, wife of Indian epics, who sacrificed everything for her husband. Thus, the wife is expected to be immensely devoted to her husband at the cost of her own pleasures, desires, and ambitions. This ideal wife has to be sexually pure and epitomize sexual fidelity, she is responsible for all household chores, taking great care of her husband and children, and is expected to lead her remaining life embracing her husband's memories, once she becomes a widow. Through the ideas of loyalty and obedience to the husband, Hindi cinema successfully institutionalized patriarchal values. Films like Dahej (1950), Gaur (1968), Devi (1970), Biwi ho to Aisi (1988), Pati Parmeshwar (1988) depicted women as passive, submissive wives and perfect martyrs for their families. In these films, practices of patriarchy were implicitly patronized in the sense that the victim wife refuses to leave her husband's house despite severe physical and emotional violence. The idea is further reinforced by perpetuating Indian traditions and symbols like entering the husband's house at the time of marriage in a "doli" and leaving only at the time of death in an "arthi".

Representation of women in Bollywood is based on Manichean dualism where women are presented as one-dimensional characters that are good or bad. This dichotomy was reinforced in popular films, which distinguished between the heroine and the vamp, the wife, and the other woman. Being true to this tradition contrary to the atypical 'pure' woman of Hindi cinema another 'impure' image is also propagated, that of the stereotyped 'vamp', she is exactly the opposite of the role of an ideal wife or mother. The vamp is characterized as a woman who shows disrespect for tradition by emulating Western women. Furthermore, she smokes, drinks, parties and is promiscuous. Thus rendering her immoral, with unacceptable and offensive behavior. By creating this binary it is demonstrated how the 
Madonna-whore complex functions in the Indian community. Madonna, symbolizes the girlfriend or wife, while the vamp is a whore, and as usual, is expected to be unchaste and impure [2]. Mother, daughter, wife or vamp, whatever the role-played by the woman in Hindi cinema one thing remains consistent, she has little agency in the industry and serves only as a strategic instrument. Talking about the vamp one woman who surpasses all others is Helen followed closely by Aruna Irani and Bindu. Helen Ann Richardson played the stereotyped role of the classic vamp in many movies made in the sixties. This Burmese-born actor played the role of a nautch dancer and acted in more than seven hundred movies. Despite being very popular she was never offered the role of a leading lady in any of the movies she worked in. She set the screen ablaze by her dance numbers in songs like "Piya Tu Ab To Aaj"-Caravan (1971) and "Mera naam chin chin chu" -Howrah Bridge (1958), yet she emerges as the most stereotyped and marginalized female actors in the history of Indian cinema.

\section{PATRAIRCHY AND DISCRIMINATION}

Film scholar and author Shoma says, "Women in Hindi cinema have been decorative objects with rarely any sense of agency being imparted to them. Each phase of Hindi cinema had its own representation of women, but they were confined largely to the traditional, patriarchal framework of the Indian society. The ordinary woman has hardly been visible in Hindi cinema"[3]. She is stripped of any kind of identity devoid of any agency and her function is to be seen only through the eyes of the male protagonist. This depiction limits the women's role to providing glamor, relief, respite, and entertainment. For eg: Priyanka Chopra's character in Agneepath (2012) is insignificant as such. She is a glamorous object that is present in the movie to provide relief from the senseless violence and melodrama that the lead actor engages in throughout the movie. Same kind of role is enacted by Mahira Khan in Raees (2017) and Katrina Kaif in Dhoom3 (2013), they fulfill the role of an objectified female actor whose only purpose in the entire movie is to show the lead male actor in a better light. In all the said movies it seems the heroine is abruptly placed in the romantic track as a distraction for the viewer from monotonous bouts of melodrama. One single dominant function of a female character is to serve as an "object of desire for men, just like her Hollywood and British counterparts" [4]. Women in commercial Indian films are often seen dancing in wet sarees to cater to men's erotic fantasy. This wet saree dance is described by Richard (1995) as, "legitimized by a sudden, torrential downpour that soaks the woman's flimsy saree, and allows for a very provocative and tantalizing exposure of the female body" [5]. The rain-saree-dance image is exploited in many movies, like Mr. India (1987), Janbaaz (1986), Mohra (1994), Ram Teri Ganga Maeli (1985), Satyam Shivam Sundaram (1978) and many more. The idea being that a downpour some how legitimizes the exposure of the lead actress and absolves her of any guilt, the logic being that it is not the fault of the lady as she is an innocent victim of the weather. Hence, exposure of fair skin, svelte body provocative dance moves emerge as a fetish shared by most filmmakers, as the chief function of the female actors seems to be to titillate the male audience. Augmenting this rain dance there exists a whole genre of movie songs called the 'item number', which showcases a svelte woman dancing to western beats in skimpy clothing. These songs are strategically placed in the movie often without any direct connection with the rest of the film, to attract audiences. Sometimes the one item song ends up making a film a hit, such as Oh La La from The Dirty Picture (2011), Chikini Chameli from Agneepath (2012), or Munni Badnaam Hui from the movie Dabangg (2010). In these songs, the styling in terms of make-up and costumes, and the angles in which the routine is shot are all designed to attract the male gaze. And to emphasize these unnaturally distended body proportions, the women are frequently shot either from a low angle or from a high angle to show legs and cleavage. The actions of the women in the dance often mimic sexual movements with numerous shots of just body parts, like that of heaving breasts, or pelvic thrusts. All these add up in objectifying and sexualizing the body of the woman for the benefit of the male viewer.

Most of the women projected in Hindi movies are not defining characters that make their own choices and live by them. Two individuals, male and female might make the same choices in the movies yet the consequences of those choices are opposite. A woman wearing revealing clothing, smoking, drinking, or even having multiple lovers is not viewed as the same as a man who makes identical choices. The woman acquires an image of impurity and sin. The way in which these nuances are portrayed on screen has an undercurrent, which carries explicit messages to the audience, reinforcing further, the pre-existing stereotypes. Hence the pertinent question, do films lead to socio- cultural stereotypes or do these stereotypes find their way into films? In David Dhawan's Biwi no.1 (1999), the wife played by Karishma Kapoor sacrifices her career to be with her husband Salman Khan. When he strays and forges an illicit relationship with Sushmita Sen the blame is not shared equally by the two, Sushmita is demonized for the affair whereas Salman Khan is accepted back by the wife and brought back into the clichéd marriage fold. The significance of the title i.e. Biwi no.1 is because the wife is successful in bringing the husband back to the domestic arena - seen as the victory of the traditional wife over the modern mistress. Such a portrayal has strong moral connotations associated with it. On the other, hand when Tabu commits adultery in Astitva (2000), she is ostracized by her husband, son, and society for her single act of weakness. These types of portrayals on screen lend legitimacy to oppression and suppression of women in Indian society.

If we have to specifically point to an era in the Indian filmmaking history that was especially detrimental to the feministic cause of the Indian woman it would be the cinematic productions of the 90s. What makes the 90s film specifically interesting is the sheer number of films made during this decade. Bollywood released close to 185 movies over a period of 10 years. After analyzing this list of movies it is fairly safe to conclude that the genre called 'family drama' rules the roost. Although it was popular before both with the makers and cinemagoers, earlier these family dramas co-existed with other genres, while the 90s have produced these movies to the near extinction of others. Keeping the larger audience in view, including the expatriate community 
and some part of the foreign population, these films tend to evoke the nostalgia of a happy domesticity among the first generation immigrants and at the same time present an image of an exoticized Indian culture/ tradition/ way of living, to the foreigner. Conforming to Said's theory of Orientalism, [6] these movies reinforce didactic models of values of 'Indian' life in contrast to the more refined individualistic way of the West. If looked at from a more political point of view these movies possess pronounced right-wing leanings. They speak very specific right wing rhetoric. Vinay Lai in his essay, "The Impossibility of the Outsider in the Modern Hindi Film" comments, "As the idea of India as a nation-state takes precedence, the idea of India as a civilization will become imperiled, and the cultural pluralism and accommodation of that civilization will most likely become, as they have already to some degree, the first victims of that nefarious development" [7], and Indian movies seem to be a fatality of this idea.

\section{CINEMA IN 90s}

Virginia Woolf's A Room of One's Own expresses the ironical paradox of a woman's life. "Men need her, love her, worship her and write about her. But they do so in relation to their own selves" [8]. Directors like Sooraj Barjatya and Karan Johar were at the forefront of such films and the women projected in the movies are subordinate to their male counterparts. They act as repositories, upholding traditional values of culture and traditions. They become signified of vast signifier - nation/ culture/ history/ traditions, and authenticators of a national/cultural identity. The body of the woman is the carrier of cultural signs; symbols of marriage like the mangalsutra and sindoor are fetishized. Considering the fact that family is a significant social unit in the rhetoric of the Right, celebrating the big Indian family in these movies present to the viewer an exoticized home/nation metaphor, where festivals are celebrated and rituals observed, accompanied with designer costumes, fire works, fine jewelry, lights and beautiful people dancing to loud music, like the Diwali song in Kabhi Khushi Kabhi Gham (2001). All such family events reinforce the idea of a strong, stable family as a microcosm of a strong, stable nation. There is a rigid hierarchy in the family structure characteristically headed by a dominant male that calls upon the young members to live by its rules. In this structure, women have their demarcated spaces in which they fulfill their designated tasks. Their identity is constituted within and through the family; they turn into a central trope on which rests the Hindutva notion of woman as a subservient entity. Such family oriented films essentially talk about family bonding and have women playing larger than life roles centered around values like love, care, discipline, obedience etc. Eg: Kajol in Kuch Kuch Hota Hai (1998), Madhuri Dixit in Hum Aapke Hain Kaun (1994) and Dil To Pagal Hai (1997), Jaya Bachchan in Kabhi Kushi Kabhi Gham (2001). While women secured very important roles in these movies their agency was absent. They were glamorous women in designer outfits, perfect makeup and hair that gyrated to upbeat songs. Their roles were defined in relation to their family especially the male characters in the family. They were lightening years away from real flesh and blood women who worked for a living, changed with the changing situations in their lives and asserted their identity. Even though these women are showcased as an Indian woman in modern avatar donning skimpy western attire, they still possessed this ability to burst into a bhajan or a national anthem amidst large gatherings, like Kajol in Kabhi Khushi Kabhi Gham or Rani Mukherjee in Kuch Kuch Hota Hai. The narratives of the films analyzed are not just didactic in a literal, distasteful way but these films are huge box office hits. These films push forward norms/prescriptions for the youth that form large segments of the audience. They continue to enthrall audiences everywhere, resulting perhaps, slowly and steadily in a transformation of the way we think and behave in our worlds. Laura Mulvey writes, about Hindi cinema "Men act, women appear. Men look at women; women watch themselves being looked at" [9]. In Indian cinema, women have been relegated to the passive position in film after film, as "bearer, not the maker of meaning”, merely as supporting cast to the man, who is the wielder of power. What Budd Boeticher says about the narrative cinema in the West also applies here: "What counts is what the heroine provokes, or rather what she represents. She is the one, or rather the love or fear she inspires in the hero, or else the concern he feels for her, who makes him act the way he does, in herself the woman has not the slightest importance" [9], the recent disappointing example of this genre being the movie, Kaabil (2017). Sanjay Gupta directs a senseless, bloody revenge drama where Hrithik Roshan takes center stage to avenge the rape of Yami Gupta. Interestingly, Yami, who is the victim is relegated to the margins and hardly gets an opportunity to express the psychological implications of rape. The story turns into a showcase where Hrithik Roshan flexes his toned muscles and wreaks havoc. This, unfortunately, is a very popular genre of movies made in India, where the whole saga played out on screen is of a dominant male, their wants, their desires, their dreams, their revenge and a quest for heroism. The women exist only in relation to the men, usually reduced to a mere spectacle, pretty faces commodified for their beauty.

\section{A Time for Change: Female Directors}

Coinciding with the rise of feminism an alternative genre of filmmaking did start evolving in Indian Cinema over time; it witnessed a mild shift in sensibilities. This new trend was more sympathetic to the marginalized female and tried to deal with women's issues, give them voice and representation in the male-dominated industry. Unable to comprehend the female psyche, movies made before this only forged a subaltern interiority that made no effort to destabilize hegemonies. Confronted with the might of sound financial backing and outdone by history and culture. Interestingly as more women directors emerged on the scene they started addressing vital issues and angst experienced by women that had been largely ignored till then. As it has been argued by the feminist critiques those films portraying women's issues made by even the most liberal and impartial male directors in India still present some proportion of patriarchal tendencies, realizing the pitfalls of stereotyping they made attempts to showcase empathy and identification. This empathy, however, was conditional and regulated by an ambivalent worldview. Hum Dil De Chuke Sanam (1999), Cocktail (2012) despite being women-centric have strong patriarchal residue, such refusal is ultimately premised upon 
convenience, a hedonist intellectual and a moral vacuum- a recurrent feature of occupation. It ultimately falls back to the same tendency to stereotype. On the other hand, films made by some women, directors explored various themes like the question of female identity in a male dominated society. In movies like Water (2005), Mr. and Mrs. Iyer (2002), English Vinglish (2012), women's issues are brilliantly examined by them, most notable amongst these breed of directors were, Aparna Sen, Kalpana Lajmi, and Deepa Mehta. Women, who had always, have been a symbol of submission were for the first time given power to overcome patriarchy and carve an identity in a male-dominated Indian society. These films emerge as a charter against the all-pervading religion and culture that constructs the ideal - a virtuous woman synonymous with subservience, docile femininity and lack of agency. After analyzing the agenda of the few women-centric movies produced it is very difficult to understand why despite strong resistance to the dominant stereotypes more such movies are not made. The possible answer can be found in the difficulties faced by women directors who push a feministic agenda. Films by these directors usually face many difficulties in finding private financers. For instance, Kalpana Lajmi's Daman (2001) ended up being funded and distributed by National Development Film Corporation (NDFC), a government program offering much less money. She also served as the screenwriter and story writer of the film. In addition to the funding problem, most of her technicians, who were men, aggravated her miseries because they were either new to the business or did not deliver quality work. She was severely criticized for portraying very aggressive central characters and her movies received a fair share of negative criticism on technical issues. Lajmi angrily addressed these issues in an interview, where she said, "it's easy for someone to slash a woman- centric film. They don't see what goes into making a film. And with the kind of budget we get, what do they expect us to make? Even if we get half the money that producers of commercial films get, we can create wonders" [10]. Even actress Kareena Kapoor, on the music release of her woman-centric film Heroine, confessed, "although women-centric films are being appreciated, and are more in number than they used to be in the past, the truth still remains that in a male-dominated industry, women are given a secondary treatment, and they will continue to be shown as glamorous dolls and will perform insignificant roles” [11]. In fact, various actresses have a mentioned on many occasions that it is very difficult, nearly impossible for women-centric movies to make half as much money as the films with male superstars in them.

\section{CONCLUSION}

India is a large country with diverse groups of people. Women from one region differ substantially from other geographic divisions. It is not easy to homogenize the whole gender to give them one voice. They come from different backgrounds, be it socio-economic status, religion or caste, they have different kinds of ambitions and desires as a result of which they lead different lives. Ideally, different women have to be located in varied films, so as to provide them with an agency to dismantle oppressive stereotypes. Women have to be provided with strong role models who possess an individualistic identity and help female audience in negotiating a unique position within the existing power structures. Progressive cinema can become a tool for social change, a change for the better.

\section{REFERENCES}

[1] M. A. Hogg and D. J. Terry, Social Identity Processes in Organizational Contexts, S. l.: Psychology Press, p. 90, 2002.

[2] S. Nandkumar, "The stereotypical portrayal of women in commercial Indian cinema,” M.A. Thesis, University of Housten, pp. 33-34, 1993.

[3] Role of women in Indian cinema (March 3, 2017). [Online]. Available: http://oorvazifilmeducation.wordpress.com/2010/10/08/interview-wit h-shoma-chatterji-role-of-women-inindian-cinema

[4] M. Pendakur, Indian Popular Cinema: Industry, Ideology, and Consciousness, Cresskill, NJ: Hampton Press, 2003.

[5] K. M. Gokulsing and W. Dissanayake, Indian Popular Cinema: A Narrative of Cultural Change, Thretham Books Limited: London, p. 81, 2004.

[6] E. W. Said, Orientalism, New York: Pantheon Books, 1978.

[7] V. Lai, “The Impossibility of the outsider in the modern hindi film," in The Secret Politics of Our Desire, Ashis Nandy, Ed. Delhi: Oxford University Press, 1998, p. 99.

[8] V. Woolf, A Room of One's Own, New York: Harvest, p 41, 1989.

[9] L. Mulvey, "Visual pleasure and narrative cinema," in Film Theory and Criticism, Leo Braudy, Ed. New York: Oxford University Press, 1999, p. 15837.

[10] K. Lajmi. (March 3, 2017). Distributors’ quandary. [Online]. Available: http://timesofindia.indiatimes.com/entertainment/hindi/bollywood/ne ws/Kalpana-Lajmi-Distributors-quandary/articleshow/27732610.cms?

[11] K. Kapoor, Film Tadka, Sept. 17, 2012.

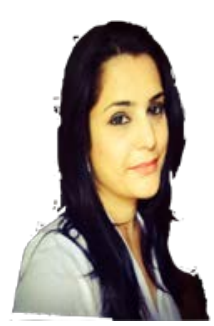

Abina Habib is an assistant professor presently working in the Department of English, Amar Singh College, Srinagar. She is a native Indian and received her doctorate from the University of Kashmir. She teaches undergraduate and postgraduate courses in English literature that include, the short story, novels, and poetry. Her current research interests include the history and appropriation of English language, literacy studies and the impact of globalization on native literature. 